\title{
Anti-idiotypic Antibodies to Poliovirus Antibodies in Commercial Immunoglobulin Preparations, Human Serum, and Milk
}

\author{
M. HAHN-ZORIC, B. CARLSSON, S. JEANSSON, H. P. EKRE, A. D. M. E. OSTERHAUS, \\ D. ROBERTON, AND L. A. HANSON \\ Departments of Clinical Immunology [M.H.-Z., B.C., L.A.H.] and Clinical Virology [S.J.], University of \\ Göteborg, Sweden; Department of Haematology, $R \&$ D Immunobiology, Kabi Pharmacia, Biopharma, \\ Stockholm, Sweden [H.P.E.]; Rijksinstituut voor Volksgezondheid en Milieuhygiene, Bilthoven, The Netherlands \\ [A.D.M.E.O.]; and Department of Paediatrics, Adelaide Children's Hospital, North Adelaide, Australia [D.R.]
}

\begin{abstract}
Our previous studies have suggested that fetal antibody production can be induced by maternal antiidiotypic antibodies transferred to the fetus via the placenta. We tested commercial Ig, sera, and milk for the presence of anti-idiotypic antibodies to poliovirus type 1, using affinity chromatography combined with ELISA systems and virus neutralization techniques. Our results indicate that commercial Ig, serum, and milk samples contain antibodies recognizing idiotypic determinants on antibodies to poliovirus. Several lines of evidence support this conclusion. Thus, in an ELISA with poliovirus as a solid phase, binding of specific antibodies could be inhibited by addition of an eluate from the Ig preparation containing anti-idiotypic antibodies against poliovirus type 1. Also, antiidiotypic antibodies from pooled human $\mathrm{Ig}$, serum, and colostrum samples against poliovirus bound directly to solid-phase-attached MAb against poliovirus type 1. In addition, in a competitive inhibition ELISA, where antiidiotypic antibodies isolated from the Ig preparation competed with the poliovirus antigen for binding to monoclonal or polyclonal idiotypic antibodies on the solid phase, inhibition of antigen binding was seen at low antigen concentrations. When single-donor serum or milk was used, this inhibition was even more pronounced and could be demonstrated at almost all antigen concentrations. The finding that anti-idiotypes are present in maternal serum and milk imply, in agreement with our previous studies, that antiidiotypes may actively induce a specific immune response in the fetus without previous exposure to the antigen by being transferred across the placenta or by being passively transferred to the newborn via mother's milk. (Pediatr Res 33: 475-480, 1993)
\end{abstract}

\section{Abbreviations}

anti-id/polio, anti-idiotypic antibodies against poliovirus type 1

id/polio, idiotypic antibodies against poliovirus type 1

KSCN, potassium thiocyanate

PBS-T, PBS containing $0.05 \%$ Tween 20

RF, rheumatoid factor

Received March 17, 1992; accepted December 9, 1992.

Correspondence: Mirjana Hahn-Zoric, Department of Clinical Immunology, Guldhedsgatan 10, S-413 46 Göteborg, Sweden.

Supported by grants from the Swedish Medical Research Council (no. 215), the Ellen, Walter, and Lennart Hesselman Foundation, Kabi Pharmacia, Stockholm, and the Medical Faculty of the University of Göteborg, Sweden.
In an earlier study of the ontogeny of secretory immunity in man, specific secretory IgA and IgM antibodies to Escherichia coli $\mathrm{O}$ antigens and poliovirus type 1 antigen were found in saliva, meconium, and amniotic fluid of infants at birth, indicating antigen-specific antibody production during fetal life (1). This finding was recently supported by similar observations in infants of hypogammaglobulinemic or IgA-deficient mothers, who had no $\operatorname{IgA}$ and/or IgM antibodies themselves $(1,2)$. It is unlikely that these infants can have been exposed to poliovirus antigen in utero; there are no circulating wild or vaccine poliovirus strains in Sweden because almost the whole population is routinely vaccinated against poliomyelitis with an inactivated vaccine only. Therefore, we have searched for an alternative explanation for the occurrence of such specific $\operatorname{IgA}$ and $\operatorname{IgM}$ antibodies. It was speculated that these antibodies might have been induced by transplacentally transferred maternal anti-idiotypic antibodies $(1,2)$. If so, such antibodies should also be present in the Ig given prophylactically to the mothers with hypogammaglobulinemia.

To test this hypothesis, we used the poliovirus antigen-antibody system as a model to investigate whether or not commercial $\mathrm{Ig}$, human sera, and milk may contain anti-idiotypic antibodies to this virus.

\section{MATERIALS AND METHODS}

Antibody samples. Several batches of a commercial pooled human polyclonal Ig preparation for intramuscular injection (Gammaglobulin Kabi 16.5\%, Kabi Pharmacia, Stockholm, Sweden) were used as a source of poliovirus type 1 idiotypes and anti-idiotypes. This product consists of approximately $99 \% \mathrm{IgG}$ with only traces of $\operatorname{IgA}(<0.01 \%)$ and $\operatorname{IgM}(<0.005 \%)$ and contains about $20 \%$ IgG dimers.

Sera from four adults previously vaccinated with the inactivated poliovirus vaccine were tested $7 \mathrm{~d}$ after a booster immunization. Four colostrum samples collected on the 2 nd or $3 \mathrm{rd} \mathrm{d}$ of lactation, from mothers previously immunized with the inactivated vaccine and a milk pool from previously vaccinated mothers, were analyzed as well.

Antigens. Monomeric poliovirus type 1 antigen (D-antigen standard, Mahoney strain, $50 \mathrm{mg} / \mathrm{L}$ protein) and concentrated inactivated type 1 poliovirus vaccine, $95 \%$ composed of $\mathrm{D}$ antigen $(720$ or $180 \mathrm{mg} / \mathrm{L}$ protein), were produced at the Rijksinstituut voor Volksgezondheid en Milieuhygiene, Bilthoven, The Netherlands.

Antisera and enzymes. IgG fractions of polyclonal bovine antipoliovirus type 1 , D-antigen-specific, of polyclonal rabbit antipoliovirus type 1 and of four MAb against poliovirus type $1, \mathrm{D}$ antigen-specific, designated 3-4E4 (IgG1 isotype), 2-20FW (IgG1 
isotype), 7D7D8 (IgG2a isotype), and 5D9D6 (IgG2b isotype), were produced at the Rijksinstituut.

In the ELISA, rabbit anti-human IgG (Dakopatts Immunoglobulin AS, Copenhagen, Denmark), $\mathrm{F}\left(\mathrm{ab}^{\prime}\right)_{2}$ of goat anti-rabbit IgG (Sigma Chemical Co., St. Louis, MO), and $\mathrm{F}\left(\mathrm{ab}^{\prime}\right)_{2}$ mouse anti-human IgG conjugated to alkaline phosphatase (Jackson Immuno Research Laboratories, West Grove, PA) were used. Affinity-purified $\mathrm{F}\left(\mathrm{ab}^{\prime}\right)_{2}$ goat anti-human IgM and IgA antibody, biotin-conjugated (Tago Inc., Burlingame, CA) with avidin-conjugated alkaline phosphatase (Sigma), were used in certain experiments.

Preparation of immunoadsorbent. Poliovirus type 1 D-antigen was concentrated to $1 \mathrm{~g}$ protein/L, dialyzed against a carbonate buffer $\left(0.1 \mathrm{M} \mathrm{NaHCO}_{3}+0.5 \mathrm{M} \mathrm{NaCl}, \mathrm{pH} 8.3\right)$ and coupled to cyanobromide-activated Sepharose $4 \mathrm{~B}$ (Kabi Pharmacia) at a concentration of $1 \mathrm{~g}$ protein/L swollen gel, using the procedure recommended by the manufacturer. Ten $\mathrm{mL}$ of human Ig were slowly passed through a 1-mL column made of this material. Antibodies to poliovirus type 1 were eluted with $3 \mathrm{M} \mathrm{KSCN}$ at $\mathrm{pH} 7$, dialyzed against coupling buffer, $\mathrm{pH} 8.7$, and then coupled to cyanobromide-activated Sepharose $4 \mathrm{~B}$ at a concentration of 1 g protein/L swollen gel. A new 1-mL column (diameter- $10 \mathrm{~mm}$, BioRad Laboratories, Richmond, CA) was prepared with this material.

Adsorption of Ig preparation. Whole-mouse serum coupled to agarose (Sigma) was used to adsorb anti-mouse Ig activity in the pooled human Ig preparation for the competitive inhibition assay (see below). Adsorption was followed by dialysis and concentration to the original volume. The completeness of the adsorption was tested by ELISA. In all other experiments where mouse proteins were present, anti-mouse activity was eliminated by adding 10\% normal mouse serum (Calbiochem, Behring Diagnostics, La Jolla, CA) to all diluents.

Isolation and purification of antibodies. To separate the idiotypes from the anti-idiotype, the samples analyzed were passed through the poliovirus type 1 D-antigen-coupled immunosorbent column. Id/polio were isolated by elution with $3 \mathrm{M} \mathrm{KSCN}$ and collected in 1-mL fractions and OD was measured at 280 $\mathrm{nm}$. The most protein-rich fractions were dialyzed against PBS, $\mathrm{pH} 7.2$, concentrated in dialysis tubing in $20 \mathrm{M}$ polyethylene glycol, and stored at $4^{\circ} \mathrm{C}$ until tested.

To isolate the anti-id/polio, the sample was incubated with the id/polio-coupled immunosorbent for $1 \mathrm{~h}$ at room temperature. Bound antibodies were eluted with $3 \mathrm{M} \mathrm{KSCN}$, and the protein content was measured. To purify the anti-id/polio from possible leakage of id/polio from the column, as determined by ELISA, some of the eluates were passed up to 10 times through the antigen-coupled immunosorbent. Antigen or id/polio could not be demonstrated in the eluates using the direct binding method described below and incorporating an anti-poliovirus $\mathrm{MAb}$ for detection.

Antibody determinations and antigen detection. For antibody determination, ELISA were used $(2,3)$ in a number of different systems, with certain conditions common for all of them. Samples were always run in duplicates. Rigid microtiter plates (polystyrene, Dynatech, Alexandria, VA, or NUNC-Immuno Plate I, Roskilde, Denmark) were coated with $100 \mu \mathrm{L}$ per well of an optimal concentration of antigen or antibody diluted in PBS. After incubation overnight and blocking with BSA in PBS (PBS$1 \%$ BSA, ICN Immuno Biologicals, Lisle, IL) or $1 \%$ fish gelatin (Sigma) for 1 to $2 \mathrm{~h}$ at $37^{\circ} \mathrm{C}, 100 \mu \mathrm{L}$ of samples in 10 -fold dilutions in PBS-T (Merck, Darmstadt, Germany) and 1\% BSA or gelatin were added to the plates and incubated for $4 \mathrm{~h}$ at room temperature. Plates were washed between each step three times with PBS-T. Antisera for detection were always conjugated to alkaline phosphatase and used in optimal concentrations. One hundred $\mu \mathrm{L}$ were added to each well and incubated overnight at room temperature. After addition of $100 \mu \mathrm{L}$ of Sigma 104 phosphatase substrate $1 \mathrm{~g} / \mathrm{L}$ ( $p$-nitro-phenylphosphate disodium, Sigma) in $1 \mathrm{M}$ diethanolamine buffer, $\mathrm{pH} 9.8$, containing 0.001 $\mathrm{M} \mathrm{MgCl}_{2}$, the absorbance at $405 \mathrm{~nm}$ was recorded after appro- priate reaction time and extrapolated to $100 \mathrm{~min}$, using a Titertek Multiscan (Flow Laboratories, Ayrshire, Scotland). The same procedure for enzyme-substrate reactions was used in all ELISA systems. A control in which sample was omitted was always included.

For determination of total IgG in the samples, an IgG-ELISA was performed, in which rabbit anti-human IgG (concentration $4.5 \mathrm{mg} / \mathrm{L}$ ) was used for coating at room temperature. After blocking, rabbit anti-human IgG conjugate in the same concentration as nonconjugated antisera was used. The presence of IgG was checked in all fractions investigated.

To determine the antigen-specific IgG antibodies in the $\mathrm{Ig}$ preparations, serum, and milk, as well as in eluted samples of id/polio and anti-id/polio from the Ig preparations, a poliovirus ELISA was performed as previously described $(3,4)$; the plates were coated with $0.5 \mathrm{mg} / \mathrm{L}$ of poliovirus type $1 \mathrm{D}$-antigen at $4^{\circ} \mathrm{C}$. This procedure was also used to control the completeness of purification of the anti-id/polio-containing eluate from id/polio, which either might have leaked from the anti-poliovirus column or might have been eluted together with the anti-id/polio by formation of idiotype-anti-idiotype complexes.

Inhibition experiments were performed using ELISA in which either soluble poliovirus type 1 antigen or anti-id/polio isolated from the Ig preparation was used to inhibit the binding of id/ polio to the solid-phase-bound poliovirus type 1 antigen (Fig. 1). The Ig preparation in concentrations from 1.6 to $16 \mathrm{mg} / \mathrm{L}$ was incubated for $1 \mathrm{~h}$ at $37^{\circ} \mathrm{C}$ with serial dilutions of either poliovirus type 1 antigen or eluted anti-id/polio. The concentrations of soluble antigen used were 10 to 50 times the concentration of antigen used for coating. The poliovirus ELISA was then done as described. Inhibition was calculated as the percentage of the uninhibited antibody control (without poliovirus type 1 antigen or eluted anti-id/polio):

$\%$ inhibition $=$

$\frac{\text { uninhibited (OD 405) - inhibited (OD 405) }}{\text { uninhibited (OD 405) }} \times 100$

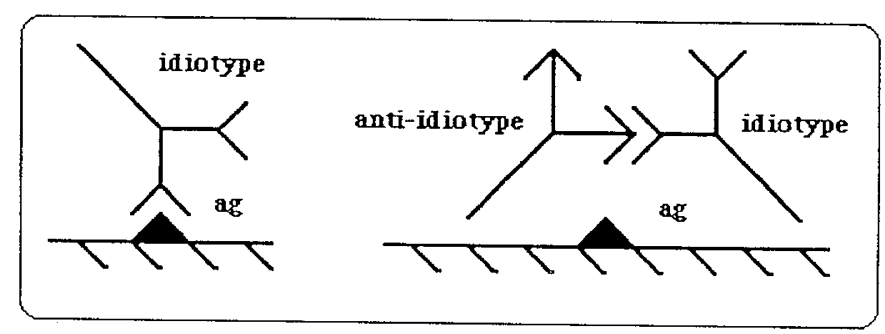

Fig. 1. Anti-idiotype may inhibit the binding of idiotype to the antigen $(a g)$.

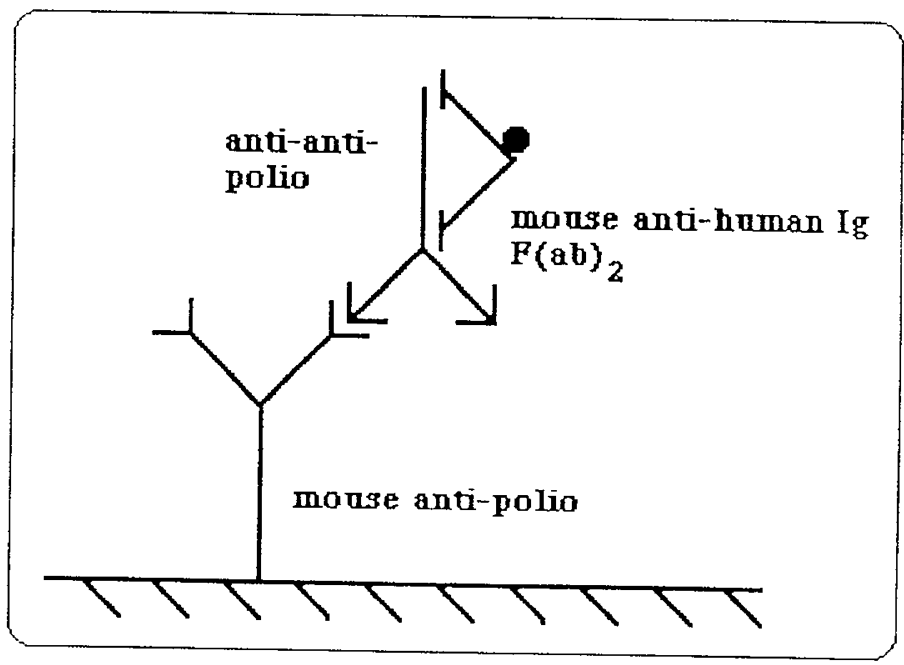

Fig. 2. Direct binding assay for detection of anti-idiotypic antibodies. 
To increase the specificity of the system, a direct binding assay was developed in which MAb or polyclonal poliovirus type 1 antibodies were used for coating at room temperature (Fig. 2). After blocking, the anti-id/polio-containing sample was diluted in PBS-T and $10 \%$ normal mouse serum and incubated in the plates. Mouse anti-human IgG conjugate was used for detection. Controls were performed in which sample and MAb were omitted. For determination of anti-id/polio of $\operatorname{IgM}$ or IgA isotype, goat anti-human IgM or IgA antibody conjugated to biotin was used, and avidin alkaline phosphatase was used in the next step.

An indirect binding assay based on the ability of anti-id/polio to inhibit the binding of the poliovirus type 1 antigen to the solid-phase-linked id/polio was developed (Fig. 3). This competitive inhibition assay was performed with the plates coated at $37^{\circ} \mathrm{C}$ with either polyclonal bovine anti-poliovirus type 1 antibody optimally diluted, three separate individual mouse MAb, or a mixture of four murine MAb against poliovirus type 1 in equal proportions at optimal dilutions. After blocking, the anti$\mathrm{id} /$ polio-containing sample absorbed for anti-mouse activity was added to the plates in a series of dilutions in PBS-T-1\% BSA or gelatin. After incubation for $4 \mathrm{~h}$ at room temperature and washing the plates, poliovirus type 1 antigen was added at appropriate dilutions in PBS-T-1\% BSA or gelatin. After incubation overnight at $4^{\circ} \mathrm{C}$, the polyclonal rabbit anti-poliovirus type 1 antibody in PBS-T-1\% BSA or gelatin was added for $4 \mathrm{~h}$ at room temperature. Alkaline-phosphatase-conjugated $\left(\mathrm{Fab}^{\prime}\right)_{2}$ goat anti-rabbit IgG diluted in PBS-T-1\% BSA or gelatin was incubated for $3 \mathrm{~h}$ at $37^{\circ} \mathrm{C}$. Results were expressed as the percentage of inhibition of the results for the noninhibited control (without anti-id/polio-containing sample). Controls were performed by omitting sample; antigen; sample and antigen; sample, antigen, and rabbit anti-polio; or antigen and rabbit anti-polio, to exclude nonspecific binding between different reagents.

Specificity of antigen-antibody binding. In all the experimental systems mentioned, the specificity of the reactions was tested and proven in a number of ways. Poliovirus type $1 \mathrm{D}$-antigen bound specifically to solid-phase-bound MAb or polyclonal antibodies against the same antigen, whereas it did not bind to $\mathrm{MAb}$ and polyclonal antibodies against a nonrelated antigen such as tetanus toxoid. Similarly, MAb against poliovirus type 1 bound only to the solid-phase-bound poliovirus antigen and not to tetanus toxoid. Furthermore, inhibition of antibody binding to the solid-phase-bound antigen was only achieved if performed with the same soluble antigen against which the antibodies were raised. Thus, inhibition of antigen binding to the solid-phasebound MAb or polyclonal antibodies against the same antigen could only be achieved by another antibody, which had to have been not only specific for the idiotype, but also antigen-like.

Test for $R F$. The absence of RF in the Ig preparations was proven in an isotype-specific diffusion-in-gel ELISA adapted for RF (5). Also, a more sensitive ELISA for detection of RF was

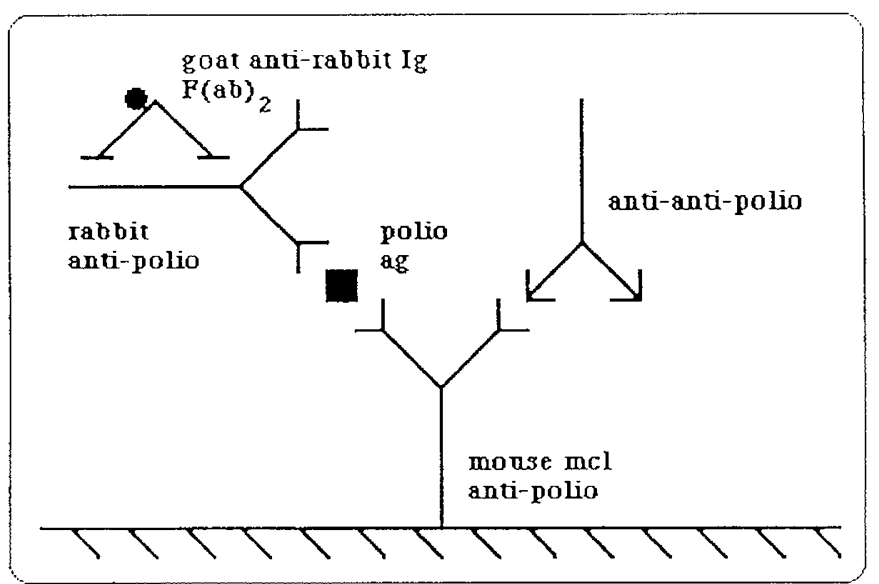

Fig. 3. Competitive inhibition assay for the indirect detection of antiidiotypic antibodies. ag, poliovirus type 1; $m c l$, MAb. run, in which soluble human $\gamma$-Fc fragments (kindly donated by Dr. B. G. Johansson, Dakopatts AS) were reacted with the samples in the direct assay, thus binding to any RF present in the samples and blocking its possible nonspecific binding to the Fc part of the MAb attached to the solid phase. Serum, colostrum, milk pool, and Ig preparation samples were mixed with different dilutions of the $\mathrm{Fc}$ fragments $(30$ to $300 \mathrm{mg} / \mathrm{L}$ ) and left to react for $1 \mathrm{~h}$ at $37^{\circ} \mathrm{C}$ before being added to the plates. The direct assay was then performed as described earlier. A control in which $\mathrm{Fc}$ fragments were omitted was used for each sample, and a strongly RF-positive as well as an RF-negative serum were included as controls.

Virus neutralization test. Levels of neutralizing anti-poliovirus type 1 antibodies were assessed in Ig samples and eluted id/polio and anti-id/polio antibodies from the same Ig samples to confirm that the id/polio had such reactivity and that the anti-id/polio lacked it. The test was done in microtiter plates with type 1 poliovirus culture according to the technique described by Halliburton and Becker (6) and modified by Grillner and Blomberg (7). The starting dilution for the samples was $1: 2$ or $1: 10$, and the final dilution was 1:256 and 1:640, respectively.

\section{RESULTS}

Evidence for presence of anti-idiotypic antibodies to poliovirus antibodies Ig preparation, serum, and milk. Binding of antibodies from human pooled Ig antibody to the solid-phase-attached poliovirus type 1 antigen in the poliovirus ELISA was inhibited by four of seven eluates presumably containing anti-id/polio. Mean inhibition of this binding was 33\% (median 18\%) for the four inhibiting samples (Table 1). Inhibition of antibody binding by the soluble poliovirus type 1 antigen was achieved in all control experiments (six of six). With the concentrations of the soluble poliovirus type 1 antigen used, the mean inhibition was $56 \%$ (median $64 \%$ ).

In the direct binding assay, anti-id/polio antibodies in the pooled human Ig and anti-id/polio eluates were analyzed with regard to interaction with solid-phase-attached mouse MAb against poliovirus type 1 . The Ig preparations, absorbed for antimouse activity, bound to the MAb in all experiments (11 of 11 ), whereas eluted anti-id/polio from the Ig preparations showed such binding in nine of 10 experiments. Concentrations of the Ig preparations and the eluates were adjusted to be comparable.

Serum samples from four adults who were vaccinated in childhood against poliomyelitis were collected $7 \mathrm{~d}$ after a booster with inactivated poliovirus vaccine and showed direct binding of IgG to different solid-phase poliovirus type 1 antibodies. The binding varied between individuals and $M A b$, but all the sera showed more binding to the mixture of four MAb than to the three individual MAb. Most binding was obtained to the polyclonal poliovirus type 1 antibody (Table 2).

IgG from four colostrum samples with high ELISA titers and no neutralizing capacity to poliovirus type 1 displayed direct binding to the $\mathrm{MAb}$ and polyclonal antibodies against poliovirus type 1 (Table 2).

The same serum and colostrum samples also contained IgA and IgM anti-id/polio to the MAb and the polyclonal antibodies against poliovirus type 1 (Table 3 ).

In the competitive inhibition assay, the Ig preparation analyzed caused inhibition of binding of poliovirus type 1 antigen to four murine MAb and the polyclonal bovine antibodies against poliovirus type 1 (Table 4). Because the percentage of inhibition of antigen binding depended on the concentration of the titrated antigen and varied between different batches of Ig preparation, individual samples, and solid-phase antibody, we have chosen to express the percentage of inhibition as a "maximal inhibition" obtained in each experiment.

Different batches of the Ig preparation inhibited binding of the poliovirus antigen to the mixture of the four MAb. The maximal inhibition ranged between 10 and 57\% (Table 4).

Maximal inhibition of poliovirus antigen binding to polyclonal calf anti-poliovirus antibody by the Ig preparation absorbed with 
Table 1. Inhibition of binding of poliovirus type 1 antibodies to the solid-phase poliovirus type 1 antigen by anti-id/polio and soluble poliovirus type 1 antigen

\begin{tabular}{|c|c|c|c|c|c|c|}
\hline \multirow[b]{2}{*}{ Inhibiting sample } & \multirow{2}{*}{$\begin{array}{l}\text { Source of anti- } \\
\text { poliovirus } \\
\text { type } 1\end{array}$} & \multicolumn{2}{|c|}{ No. of samples } & \multicolumn{3}{|c|}{$\begin{array}{c}\text { Maximal inhibition of positive } \\
\text { samples (\%) }\end{array}$} \\
\hline & & Tested & Inhibiting & Mean & Median & Range \\
\hline Anti-id-polio eluate from IgG & Ig & 7 & 4 & 33 & 18 & $13-83$ \\
\hline Poliovirus type 1 antigen & Ig & 6 & 6 & 56 & 64 & $26-76$ \\
\hline
\end{tabular}

Table 2. Direct binding of serum and milk $\operatorname{Ig} G$ anti-id/polio to solid-phase poliovirus type 1 antibodies

\begin{tabular}{|c|c|c|c|c|c|}
\hline \multirow[b]{3}{*}{ Sample } & \multicolumn{5}{|c|}{ Maximal binding (OD) } \\
\hline & \multicolumn{3}{|c|}{$\begin{array}{l}\text { Monoclonal anti- } \\
\text { poliovirus type } 1\end{array}$} & \multirow{2}{*}{$\begin{array}{l}\text { Mixture } \\
\text { of } 4 \mathrm{MAb}\end{array}$} & \multirow{2}{*}{$\begin{array}{c}\text { Polyclonal } \\
\text { anti-poliovirus } \\
\text { type } 1\end{array}$} \\
\hline & $3-4 \mathrm{E} 4$ & $2-20 F W$ & 5D9D6 & & \\
\hline \multicolumn{6}{|l|}{ Serum no.* } \\
\hline 1 & 0.7 & 0.7 & $\mathrm{ND} \dagger$ & 1.6 & 2.3 \\
\hline 2 & 0.9 & 0.8 & ND & 2.2 & 2.7 \\
\hline 3 & 0.9 & 0.9 & ND & 1.2 & 2.6 \\
\hline 4 & 0.7 & 0.9 & ND & 1.7 & 3.8 \\
\hline \multicolumn{6}{|c|}{ Colostrum no. } \\
\hline 1 & 0.8 & 0.7 & 0.7 & 0.8 & 1.6 \\
\hline 2 & 0.7 & 0.8 & 0.7 & 0.6 & 0.9 \\
\hline 3 & 0.5 & 0.3 & 0.4 & 0.2 & 0.5 \\
\hline 4 & 0.5 & 0.4 & 0.4 & 0.2 & 0.9 \\
\hline
\end{tabular}

* Read after 100-min enzyme reaction time; dilution 1:200.

$+\mathrm{ND}$, not done.

$\$$ Read after 30-min enzyme reaction time; dilution 1:10-1:100

mouse serum agarose varied between 7 and $50 \%$ for different batches of the Ig preparation tested (Table 4).

Anti-id/polio eluates from the Ig preparation caused inhibition of poliovirus antigen binding to the single anti-poliovirus MAb $2-20 \mathrm{FW}$ with a maximum inhibition of $21 \%$ and to the polyclonal calf-anti-poliovirus type 1 antibody with a maximal inhibition of $29 \%$ (Table 4 ).

Serum samples from four adults immunized in childhood and boostered with inactivated poliovirus vaccine were tested. These sera inhibited the binding of poliovirus type 1 antigen to the specific MAb. The binding differed in the individual sera, causing from 0 up to $100 \%$ inhibition of antigen binding compared with the uninhibited controls. Inhibition of the antigen binding to the polyclonal anti-poliovirus type 1 antibody also differed between the individuals, ranging from 1 to $63 \%$ maximal inhibition (Table 4).

Similarly, certain concentrations of all four colostrum samples with high antibody titers against poliovirus type 1 , but no neutralizing capacity, inhibited the binding of poliovirus type 1 antigen to MAb 3-4E4 up to $100 \%$. The maximal inhibition of binding to the polyclonal calf anti-poliovirus type 1 by these colostrum samples ranged between 32 and $63 \%$ (Table 4). Pooled milk inhibited binding of poliovirus antigen to the anti-poliovirus $\mathrm{MAb} 3-4 \mathrm{E} 4$ with the maximal inhibition of $51 \%$ at a $1: 50$ dilution (Table 4).

To exclude the possible interaction between RF in samples and MAb used in ELISA, the Ig preparation was tested in RFdiffusion-in-gel ELISA. The serum and milk samples and the Ig preparation were also tested in the more sensitive direct ELISA in the presence of blocking $\mathrm{Fc}$ fragments. No difference in OD was seen between the control samples without $\mathrm{Fc}$ and samples added with different concentrations of Fc. The RF-positive serum did not bind to the Fc portions of the used MAb attached to the solid phase or to the anti-idiotypic antibodies in the samples. Thus, RF did not give rise to false-positive results.

Virus-neutralizing capacity of specific antibodies and antiidiotypes. Virus neutralization tests were performed with samples containing poliovirus type 1 antibodies from human pooled Ig as well as with samples eluted after passage of pooled Ig through column with insolubilized poliovirus type 1 antigen. Both types of samples neutralized the viral cultures (titers 1/320 and 1/20). In contrast, the eluates containing anti-id/polio did not neutralize the poliovirus type 1 culture.

\section{DISCUSSION}

In this study, we present evidence for the occurrence of anti$\mathrm{id} /$ polio in human serum, milk, and different batches of a commercial Ig.

Earlier studies, performed in animal models, have indicated

Table 3. Direct binding of anti-id/polio of IgA and IgM isotypes against poliovirus type 1 antibodies in serum and milk to solidphase-bound id/polio

\begin{tabular}{|c|c|c|c|c|c|c|c|c|c|c|}
\hline \multirow[b]{3}{*}{ Sample } & \multicolumn{8}{|c|}{ Monoclonal id/polio } & & \\
\hline & \multicolumn{2}{|c|}{$3-4 \mathrm{E} 4$} & \multicolumn{2}{|c|}{$2-20 \mathrm{FW}$} & \multicolumn{2}{|c|}{ 5D9D6 } & \multicolumn{2}{|c|}{ 7D7D8 } & \multicolumn{2}{|c|}{ Polyclonal id/polio } \\
\hline & $\operatorname{Ig} A$ & IgM & $\operatorname{Ig} A$ & $\operatorname{IgM}$ & $\operatorname{Ig} \mathrm{A}$ & $\operatorname{IgM}$ & $\lg A$ & $\operatorname{IgM}$ & $\operatorname{Ig} \mathrm{A}$ & $\operatorname{IgM}$ \\
\hline \multicolumn{11}{|l|}{ Serum no.* } \\
\hline 1 & 0.3 & 2.2 & 0.4 & $\mathrm{ND} \dagger$ & 0.5 & 1.6 & 1.0 & 1.3 & 1.3 & 2.2 \\
\hline 2 & 0.4 & 2.4 & 0.7 & ND & 1.1 & 2.3 & 1.0 & 0.6 & 1.4 & 2.8 \\
\hline 3 & 0.4 & 2.0 & 0.4 & ND & 0.9 & 1.2 & 1.0 & 0.5 & 2.0 & 2.1 \\
\hline 4 & 0.3 & 1.7 & 0.6 & ND & 0.8 & 1.3 & 1.4 & 0.5 & 2.0 & 3.9 \\
\hline \multicolumn{11}{|l|}{ Colostrum no. $\ddagger$} \\
\hline 1 & 0.7 & 0 & 2.2 & ND & 1.5 & 0.6 & 1.5 & 0 & 3.2 & 1.0 \\
\hline 2 & 0.3 & 0 & 0.9 & ND & 0.6 & 0.1 & 0.6 & 0 & 1.3 & 0.5 \\
\hline 3 & 0.4 & 0 & 1.0 & ND & 0.8 & 0.2 & 0.7 & 0 & 2.2 & 0.9 \\
\hline 4 (pool) & 0.5 & 0 & 1.0 & ND & 1.2 & 0.2 & 1.2 & 0 & 2.1 & 0.4 \\
\hline
\end{tabular}

* Dilutions 1:10-1:10000.

$\dagger$ ND, not done.

$\ddagger$ Dilutions 1:10-1:1 000 . 
A HUMAN MODEL FOR DETERMINATION OF ANTI-IDIOTYPES

Table 4. Competitive inhibition of poliovirus type 1 antigen-binding to solid-phase poliovirus type 1 antibodies by anti-id/polio

\begin{tabular}{|c|c|c|c|c|c|c|}
\hline \multirow[b]{3}{*}{ Inhibiting sample } & \multicolumn{6}{|c|}{ Maximal inhibition (\%) } \\
\hline & \multicolumn{5}{|c|}{ Monoclonal anti-poliovirus type 1} & \multirow{2}{*}{$\begin{array}{c}\text { Polyclonal } \\
\text { anti-poliovirus } \\
\text { type } 1\end{array}$} \\
\hline & $3-4 \mathrm{E} 4$ & $2-20 \mathrm{FW}$ & 5D9D6 & 7D7D8 & $\begin{array}{l}\text { Mixture of } \\
4 \mathrm{MAb}\end{array}$ & \\
\hline \multirow[t]{4}{*}{ Ig preparation $(n=4)$} & 33 & 12 & 24 & 19 & 18 & 7 \\
\hline & 24 & 12 & 21 & 20 & 10 & 12 \\
\hline & 46 & 5 & 50 & 44 & 57 & 32 \\
\hline & 14 & 0 & 40 & 30 & 29 & 50 \\
\hline $\begin{array}{l}\text { Anti-id/polio eluate from Ig } \\
\text { preparation }(n=1)\end{array}$ & ND* & 21 & ND & ND & ND & 29 \\
\hline \multirow[t]{4}{*}{ Serum $(n=4)$} & 100 & 24 & ND & ND & 12 & 27 \\
\hline & 1 & 62 & ND & ND & 0 & 1 \\
\hline & 0 & 12 & ND & ND & 26 & 33 \\
\hline & 100 & 10 & ND & ND & 55 & 63 \\
\hline \multirow[t]{4}{*}{ Colostrum $(n=4)$} & 100 & ND & ND & ND & ND & 39 \\
\hline & 100 & ND & ND & ND & ND & 40 \\
\hline & 100 & ND & ND & ND & ND & 32 \\
\hline & 100 & ND & ND & ND & ND & 63 \\
\hline \multirow[t]{2}{*}{ Milk pool $(n=2)$} & 51 & ND & ND & ND & ND & ND \\
\hline & 22 & ND & ND & ND & ND & ND \\
\hline
\end{tabular}

*ND, not done.

that anti-idiotypic antibodies transferred from the mother to the offspring via milk can initiate an immune response to the original antigen in the newborn. Okamoto et al. (8) demonstrated production of respiratory syncytial virus-specific anti-idiotypic antibodies in newborn mice induced by maternal milk. Stein and Söderström (9) showed priming of newborn animals against the $E$. coli $\mathrm{K} 13$ carbohydrate after neonatal administration of idiotypic and anti-idiotypic antibodies, resulting in protection of the offspring against challenge with live bacteria. The priming was also obtained if the anti-idiotypic antibodies were injected in the mother after delivery so that the antibodies reached the offspring via the milk.

It has been noted that even immunization with xenogenic antibodies can result in anti-Ig responses (10). Female rabbits fed murine IgA antibody had anti-idiotypic antibodies against the murine antibody both in their serum and in their colostrum. Some of the antibodies were directed against the antigen-binding site, as determined by a competitive inhibition assay.

The evidence that the immune response in different species results in the formation of antibodies that express a common idiotope was provided by a murine anti-idiotypic MAb to ryegrass pollen allergen Lol $\mathrm{p}$ IV, which could inhibit the binding of mouse, human, and rabbit antisera to Lol p IV (11). These antisera could also inhibit the idiotype-anti-idiotype interactions, which suggested that the anti-idiotypic MAb was an internal image anti-idiotype.

Immunization of mice with an anti-idiotypic MAb to poliovirus induced an immune response consisting of an antibody population binding both to poliovirus and to anti-idiotypic antibodies to poliovirus (12). Such induction of an antibody response against infectious agents without administration of antigens has indicated the possibility of using anti-idiotypic MAb as vaccines (13).

The findings of specific IgA and IgM antibodies against $E$. coli $O$ antigens and poliovirus present at birth in neonates born to hypogammaglobulinemic or IgA-deficient mothers may imply that idiotypes and/or anti-idiotypes, transferred via the placenta, can induce a specific immune response $(1,2)$. This is especially interesting for the poliovirus antibodies, because it is unlikely that Swedish fetuses had been exposed to poliovirus antigen in utero. Thus, transplacental antibodies may provide not only passive protection of the offspring but may also induce active antibody production. The Ig preparation given prophylactically to the hypogammaglobulinemic mothers obviously may have contained anti-id/polio, as suggested by the present study.

An alternative to passive and active immunization of the newborn via placenta is transfer of antibodies via maternal milk. In the present study, anti-id/polio were demonstrated in individual samples of colostrum and in pooled human milk. There was inhibition of poliovirus antigen binding to the id/polio at almost all concentrations of milk, poliovirus antigen, and polyclonal or monoclonal idiotype, suggesting the presence of anti-id/polio in human milk. This finding would agree with recent observations $(14,15)$ showing better vaccine responses in breast-fed than formula-fed infants, which might have been due to an additional exposure of the infant to the anti-idiotypes from human milk.

The concept that anti-idiotypic antibodies, transferred from the mother via the placenta or the breast milk, may sensitize the fetus or the newborn against a number of antigens to which the mother has been exposed may have several implications. Such an exposure could enhance the capacity of the fetus and young infant to mount its own protective immune response, although it may also include the risk of sensitization to allergens, e.g. food allergens, possibly increasing the hazard of developing allergy during early life. Conversely, it may be possible at other dose levels of the anti-idiotype to selectively turn off antibody responses to allergens or autoantigens as part of an immunoregulatory response. The possible biologic significance of such mechanisms remains to be determined.

Acknowledgments. The authors thank to Eeva Nisshagen and Ann-Marie Månquist for their superb technical assistance.

\section{REFERENCES}

1. Mellander L, Carlsson B, Hanson LA 1986 Secretory IgA and IgM antibodies to $E$. coli $\mathrm{O}$ and poliovirus type 1 antigens occur in amniotic fluid, meconium and saliva from newborns. A neonatal immune response without antigenic exposure: a result of anti-idiotypic induction? Clin Exp Immunol 63:555561

2. Hahn-Zoric M, Carlsson B, Björkander J, Osterhaus ADME, Mellander L, Hanson LA 1992 Presence of non-maternal antibodies in newborns of mothers with antibody deficiencies. Pediatr Res 32:150-154

3. Ahlstedt S, Carlsson B, Hanson LA, Kaijser B, Mattsby-Baltzer I, SohlẢkerlund A 1978 Application of the ELISA for determination of immunoglobulin class-specific Escherichia coli antibodies. Scand J Immunol 8(suppl 7):119-124

4. Carlsson B, Zaman S, Jalil F, Mellander L, Hanson LA 1985 Secretory and serum immunoglobulin class-specific antibodies to poliovirus after vaccination. J Infect Dis 152:1238-1244 
5. Tarkowski A, Bjursten LM, Niisson L-Ä, Nygren H 1983 False positive results in class-specific rheumatoid factor (RF) assays due to interaction between $\mathrm{RF}$ and $\mathrm{Fc}$ fragments of anti-immunoglobulin indicator reagents. J Immunol Meth 58:171-182

6. Halliburton $\mathrm{G}$, Becker ME 1971 The use of Hepes buffer in microtissue culture plates for routine enterovirus diagnosis. Health Lab Sci 8:155-159

7. Grillner L, Blomberg J 1976 Haemolysis in gel and neutralization tests for determination of antibodies to mumps virus. J Clin Microbiol 4:11-15

8. Okamoto J, Tsutsumi H, Kumar NS, Ogra PL 1989 Effect of breast feeding on the development of anti-idiotype antibody response to $F$ glycoprotein of respiratory syncytial virus in infant mice after post-partum maternal immunization. J Immunol 142:2507-2512

9. Stein KE, Söderström T 1984 Neonatal administration of idiotype or antiidiotype primes for protection against $E$. coli $\mathrm{K} 13$ infection in mice. $\mathrm{J}$ Exp Med 160:1001-1011

10. Collins AM, Roberton DM, Hosking CS, Flannery GR 1991 Oral immuniza- tion with xenogenic antibodies stimulates the production of systemic and mucosal anti-idiotypic antibodies. Immunology 73:388-393

11. Zhou EM, Ozuba-Fischer JMM, Rector ES, Sehon AH, Kisil FT 1991 A murine monoclonal anti-idiotypic antibody detects a common idiotope on human, mouse and rabbit antibodies to allergen Lol p IV. Scand J Immunol 34:307-316

12. Uytdehaag FGCM, Osterhaus ADME 1985 Induction of neutralizing antibody in mice against poliovirus type II with monoclonal anti-idiotypic antibody. J Immunol 134:1225-1229

13. Sacks DL 1987 Immunization against parasitic protozoa using anti-idiotypic antibodies. Monogr Allergy 22:166-171

14. Hahn-Zoric M, Fulconis F, Minoli J, Moro G, Carlsson B, Böttiger M, Räihä $N$, Hanson LA 1990 Antibody responses to parenteral and oral vaccines are impaired by conventional and low protein formulas as compared to breastfeeding. Acta Paediatr Scand 79:1137-1142

15. Pabst HF, Spady DW 1990 Effect of breast-feeding on antibody response to conjugate vaccine. Lancet 336:269-270 